\title{
Development of student worksheet for blended learning based guide inquiry and science process skill in reduction and oxidation reaction
}

\author{
Sinda Febrilia Miharti1,*, Harizon² and Zurweni ${ }^{2}$ \\ ${ }^{1}$ Chemistry Education Study Program, Postgraduate, Jambi University, Jambi 36361, Indonesia \\ ${ }^{2}$ Departemen of Chemistry Education, Jambi University, Jambi 36361, Indonesia \\ *Corresponding author: SFM, sindafebrilia18@gmail.com
}

DOI: 10.24114/jpkim.v13i2.26979

Article history:

Received: 21 June 2021

Revised: 11 July 2021

Accepted: 16 July 2021

\begin{abstract}
This study aims to determine how the procedure for developing blended learning worksheets based on guided inquiry models and science process skills on the material of reduction and oxidation reactions in SMK. The method used in this research is to follow the Lee and Owens development model consisting of 5 stages of development, namely Analysis, Design, Development, Implementation and Evaluation. Analysis includes analysis of needs, characteristics of students, objectives, materials and technology. Design, researchers determine the schedule and development team, median specifications, prepare materials and make Flowcharts and storyboards. Development, develop LKPD according to storyboards, validated by material and media experts, and assessed by the teacher. Implementation includes group trials and effectiveness tests. Evaluation of LKPD in accordance with test results.
\end{abstract}

Keywords: Blended learning, Guide inquiry, Reaction of reduction and oxidation, Science process skill, Student worksheet

\section{Introduction}

Learning in this era is also known as 21st-century learning which requires innovation to deliver students to the future. 21th Century skill includes 3 things: (1) Life and career skill, (2) Learning and innovation skill, and (3) Information media and technology (Trilling \& Fadel, 2009). Learning must be able to make the learning process can take place continuously without the limits of space and time. Learning is not only limited in the classroom (conventional) but also outside the classroom by utilizing technology or commonly referred to as e-learning. 
Based on the results of observations at SMKN 2 Sungai Penuh, online learning conducted at SMKN 2 Sungai Penuh has encountered several obstacles including the difficulties in controlling students while learning, limitations in explaining the material, and connectivity between the material presented and the results obtained by students is not guaranteed, because when learning takes place, the teacher does not know whether students are focused on participating in learning or not, while the obstacles encountered by students include lack of information about online learning, lack of focus in following the learning provided by the teacher, and students are also easily distracted by other activities when learning activities take place.

One of the efforts that could be done in responding to the obstacles encountered by teachers and students in online learning is to apply learning with blended learning models where learning is not only by online but also with face to face for several meetings. state that this blended learning model combines face-to-face patterns in class or online. Hamon \& Jones (2005) state that this blended learning model combines face-to-face patterns in class or online.

Blended learning can be carried out more effectively and to increase student's interest and motivation, teaching materials are needed that can be used by students both online and face-to-face learning. The presence of teaching materials is expected to make it easier for students to understand the knowledge they are learning, beside that the teacher is not understood as the only source of learning, but must be able to plan and create other learning resources so to create a conducive learning environment (Munadi, 2008). Blended learning is about effectively integrating ICT into course design to enhance the teaching and learning experiences for students and teachers (Sharma, 2010). This opinion reinforces that it is important for teachers to continue and to develop media as a support for learning. One of the teaching materials in learning is the student worksheet (Silaban, 2021).

Student worksheets are sheets containing tasks that must be done by students (Trianto, 2007). In the student's worksheet, students can find structured directions to understand the material given (Lukman et al. 2019). Students are at the same time given materials and assignments related to the material. the purpose of arranging student worksheets includes presenting tasks that improve students' mastery of the material provided and train the learning independence of students (Kristyowati, 2018).

Astuti and Setiawan (2013) conducted research using a 4D development model that aims to produce student worksheet based on a guided inquiry approach in cooperative learning that is feasible and effective for science learning on heat material. Mufarohah \& Dwiningsih (2018) have also conducted research testing the effectiveness of blended learning based worksheets with the POGIL strategy on high school chemical bonding material in terms of students' pretest and posttest results. Aprilia et al. (2019) have developed student worksheets with blended learning models oriented to higher order thinking skills on business and energy materials that have been tested for feasibility and practicality so that they can be used in learning physics in high school. In this study, the student's worksheet that will be developed is the student's worksheet that can facilitate students both in online learning and face-to-face learning. Student worksheets will also be designed to follow the steps of the guided inquiry learning model and lead to the improvement of students' science process skills. 


\section{Methods}

This research is a research and development, using the Lee and Owens model framework (Lee \& Owens, 2004). The test subjects in this study were students of 1st-grade TITL at SMK Negeri 2 Sungai Penuh. Determination of validation by media experts, material experts. Quantitative data obtained in the form of product development assessments obtained from material experts, media experts, teacher response questionnaires and student response questionnaires were analyzed and processed descriptively into interval data using a Likert scale, student pretest and posttest data were analyzed using t-test statistics. In qualitative analysis, the data obtained from comments and suggestions from material experts and media experts, teacher interviews and questionnaires student responses.

\section{Results and Discussion}

The development of guided inquiry-based blended learning worksheets and science process skills follows the stages of the Lee and Owens (2004) development model which consists of 5 stages of development, namely (1) Analysis, (2) Design, (3) Development, (4) Implementation and (5) Evaluation. The products produced are online worksheet and printed worksheet which are arranged according to the syntax of the guided inquiry learning model and lead to science process skills. The student's worksheet developed has been declared feasible theoretically based on validation by experts and feasible practically by the assessment of teachers and students as practitioners.

\subsection{Analysis}

The stages of analysis carried out are: needs analysis, analysis of student characteristics, analysis of objectives, material analysis, and analysis of educational technology through interviews with chemistry subject teachers and distributing student questionnaires to 22 students at SMK N 2 Sungai Penuh. In accordance with Astuti \& Setiawan's opinion (2013) stated that practical educational problems have many studies, one of which is how to design and develop learning resources (LKPD, LDS, modules). This study begins with an analysis of the problem, context, literature and so on. This analysis directs researchers to understand the meaning of the problem to be designed and developed iteratively the solution product in order to have a potential impact that is expected to be able to solve educational problems. In line with the opinion of Khofifah \& Mitralis (2021) at the analysis stage of determining the competence to be achieved can be based on the normative standards set at the school or in their respective institutions, or it can also be based on the needs of the user, it can even be based on the needs to be studied come.

The results of the needs analysis in learning redox reaction material where this material has complex characteristics in fact there is still a gap between the learning process using teaching materials in the form of student's worksheet that has been provided with the expected competencies, especially in students' science process skills, in addition to online learning as in Currently, there are still obstacles that cause the learning process to be less effective, there are also no available teaching materials that support online as well as faceto-face learning and teachers also agree to the development of student's worksheet that supports online and face-to-face learning that can train students' science process skills.

\subsection{Design}


The design stage is continued by determining media specifications, compiling materials, and describing program control arrangements, all of which are presented in the form of flowcharts and storyboards. The manufacture of the product takes \pm 4 months starting from December 2020 to March 2021, the development of this student worksheet is carried out until a large group trial is carried out on student 1st grade TITL at SMK N 2 Sungai Penuh.

According to (Trianto, 2007) A student worksheet is a sheet containing tasks that must be done by students. The product specifications developed are blended learning worksheets that contain Reduction and Oxidation Reaction based on KD 3.7 and 4.7 in the 2013 SMK curriculum which are arranged following the steps in the guided inquiry learning model. The student worksheet is compiled by taking references from several chemistry books for SMK, examples from the internet, as well as several learning videos downloaded from the internet.

\subsection{Development}

The development stage is the stage of making products according to the storyboard that has been prepared. In this stage, the author makes a worksheet using the Canva application, which is an application to design the appearance of the worksheet to make it look attractive, then combines the material that has been prepared with a template via Microsoft Word. Online worksheets are made through the web www.liveworksheet.com. Some examples of the display of printed LKPD and online LKPD can be seen in Fig 1-4.

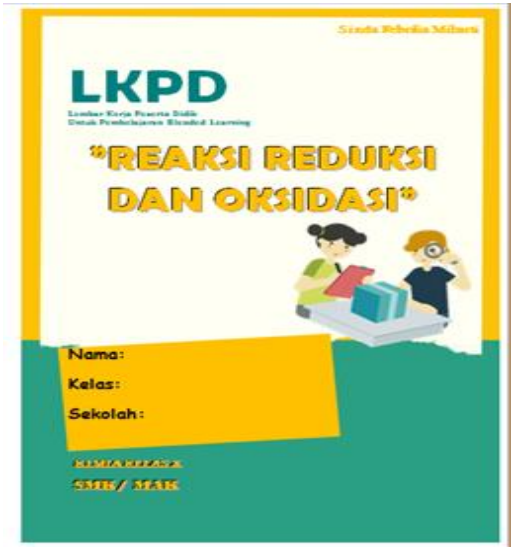

Fig 1. Display of Printed LKPD Cover

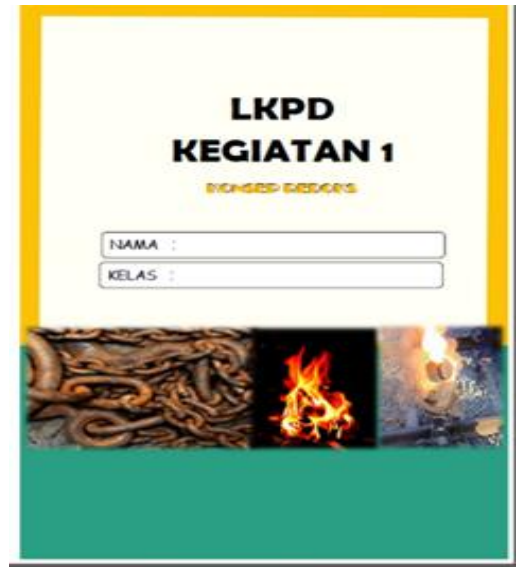

Fig 3. Display of online worksheet cover

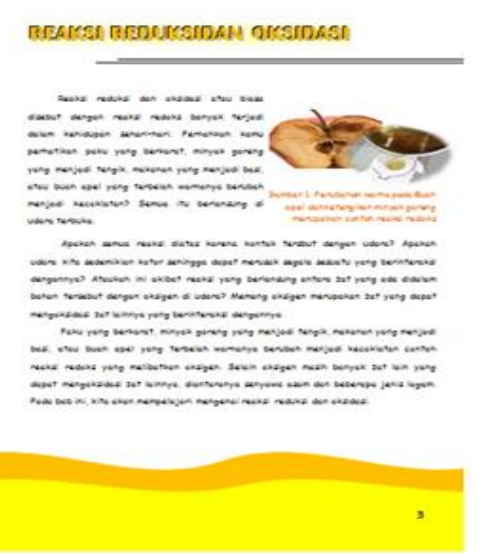

Fig 2. Display of Printed LKPD Material Pages

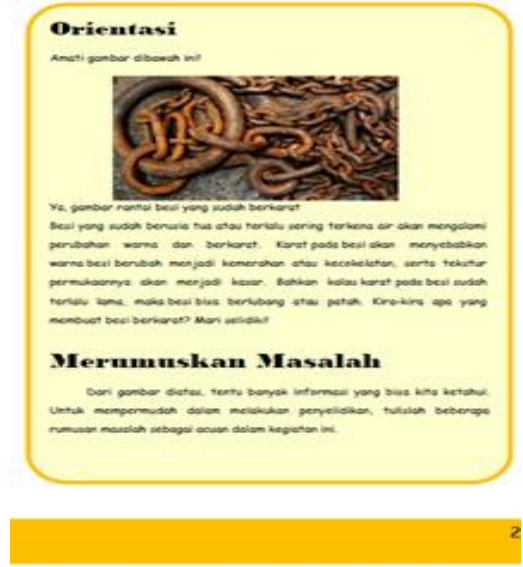

Fig 4. View page of online LKPD activities 
The worksheets that have been made are validated by material experts (Fig 5) and media experts (Fig 6) and revised according to suggestions and comments from material experts and media experts, then assessed by the chemistry teacher at SMK N 2 Sungai Penuh.

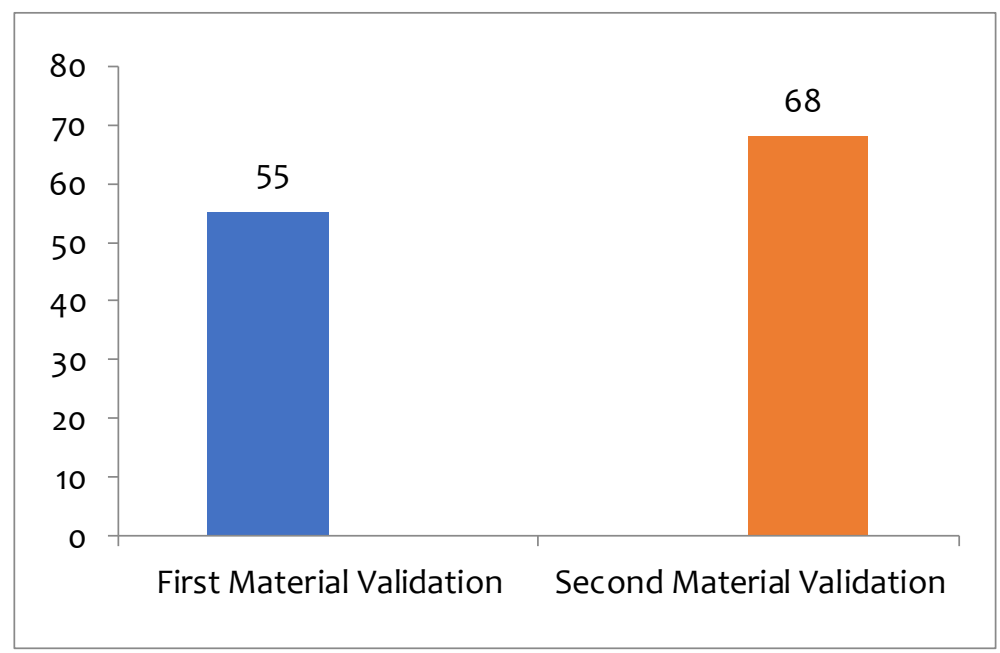

Fig 5. Material Validation Questionnaire Results

The material validation questionnaire analysis is based on the number of scores, the first material validation gets a score of 55 in the "medium" criteria. While the second number of material validation scores is 68 "good". The improvements made were improvements in the preparation of material according to the syntax of the guided inquiry model, improvement in learning indicators in accordance with KD, simplification in the presentation of concepts and redoks reaction materials, improvement in the presentation of material to make it more interesting, improvement of questions according to indicators of science process skills, improving the use of language to be simpler so that it is easier for students to understand.

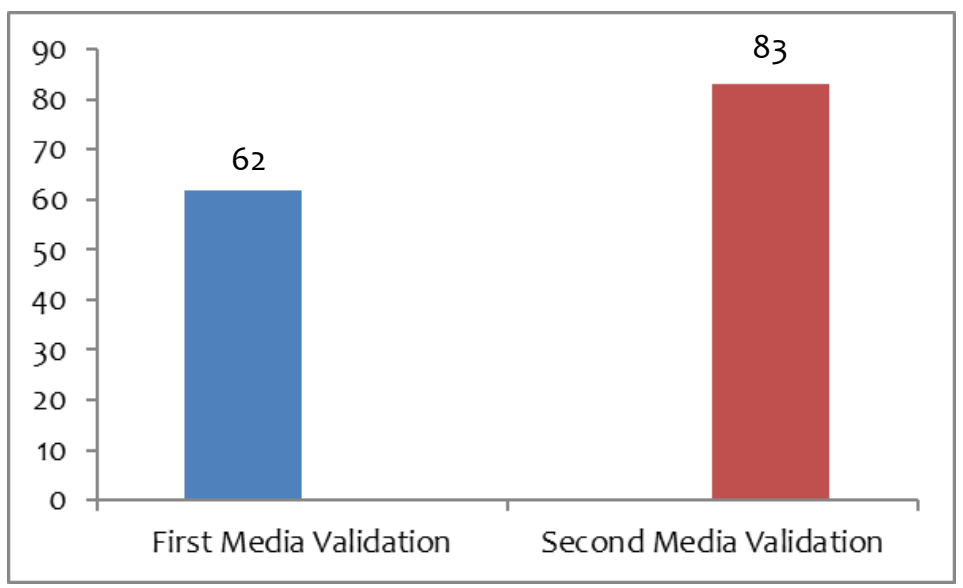

Fig 6. Media Validation Questionnaire Results

The total score on the first media validation was 62 "medium" criteria. While the second number of media validation scores is 83 with the criteria of "very good". From the results of material validation twice, then followed by media validation twice, a product that has been declared theoretically feasible can then be assessed by practitioners, namely teachers and 
students. After validation by material experts and media experts, the LKPD was assessed by a chemistry teacher at SMK N 2 Sungai Penuh with a score obtained from the teacher's assessment questionnaire of 57 in the "very good" criteria. The following are the results of the LKPD before and after the revision (Fig 7-14).

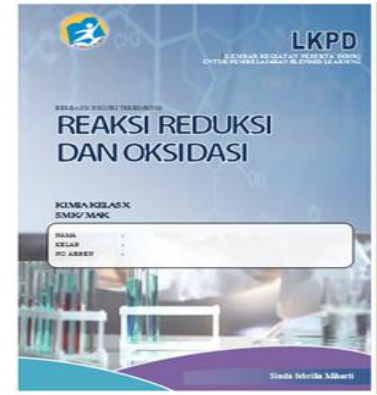

Fig 7. LKPD cover display before revision

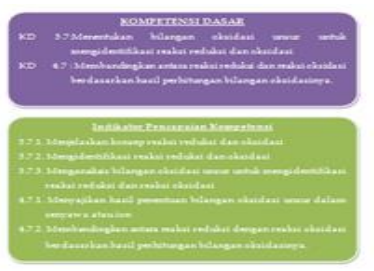

Fig 9. Display of the LKPD competency page before being revised in the revision

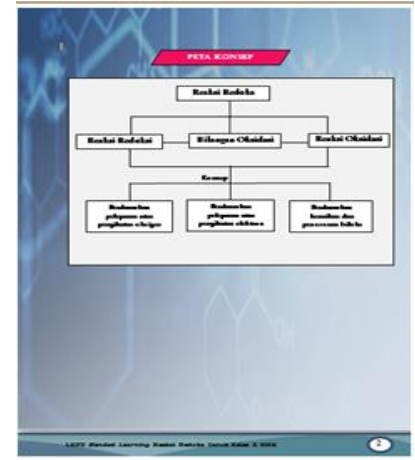

Fig 11. LKPD concept map page view before being revised in revision

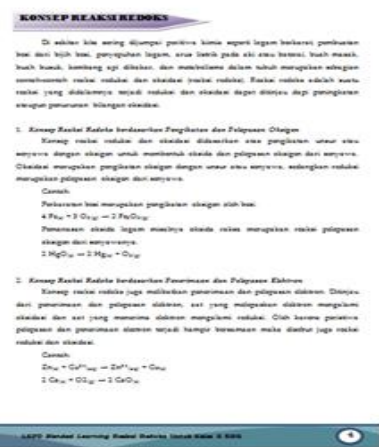

Fig 13. LKPD material page view before being revised in revision

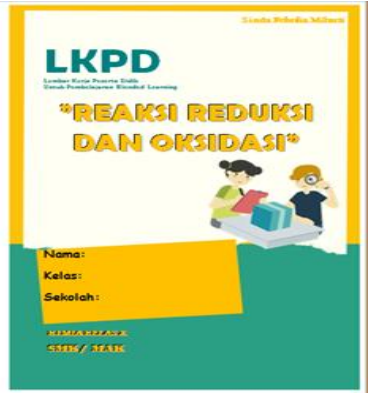

Fig 8. LKPD cover display after being revised in revision

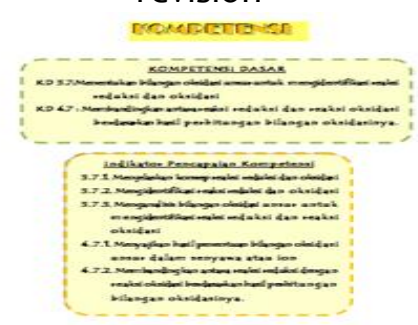

Fig 10. Display of the LKPD competency page after being revised in revision

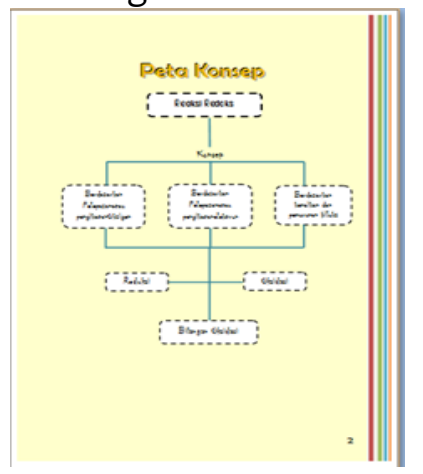

Fig 12. LKPD concept map page display after being revised in revision

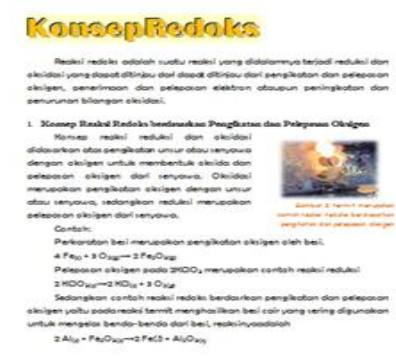

Fig 14. Display of the LKPD material page after being revised in revision 


\subsection{Implementation}

At this stage, a small group trial was conducted with the test subjects as many as 10 students of 1st grade SMK N 2 Sungai Penuh who were selected by the teacher based on the criteria for high, medium, and low cognitive levels. Furthermore, the small group test was evaluated through a student response questionnaire.

Implementation is also carried out through field trials or large groups involving one class consisting of 18 students of 1st grade TITL SMK N 2 Sungai Penuh. Before the trial, the students did a pretest first to see the initial abilities of the students, then continued with the redoks reaction material learning activities carried out with a blended learning system, following the lesson plans that had been prepared consisting of two online meetings, one face-to-face meeting and using student worksheet blended learning based on guided inquiry and science process skills.

\subsection{Evaluation}

Evaluation is a process to see whether the product being developed is in accordance with the initial expectations or not. According to (Lee \& Owens, 2004) The evaluation suggested by Lee \& Owens refers to Donald Kirkpatrick's evaluation stages with 4 levels of evaluation. Among them are (a) Level 1 Reaction, assessing user responses through their impressions of the resulting program; (b) Level 2 Knowledge, assessing the improvement in learning outcomes and skills acquired after using the program; (c) Level 3 Performance, assessing changes in user attitudes and behavior after using the program; (d) Level 4 Impact, assessing the impact of the program more broadly, can use the return of investment (ROI) evaluation type. The evaluation that is usually done to assess the easiest product is through level 1 evaluation, namely the response and level 2 evaluation, namely learning outcomes.

Level 1 evaluation is reaction evaluation, which is to assess the user's response through his impression of the program produced through small group trials. Analysis of student response questionnaire data obtained a percentage score of $85.40 \%$ with the criteria of "very good".

Level 2 evaluation is the evaluation of knowledge or assessment of learning outcomes through large group trials from one class, namely 18 students of class 1st grade TITL SMK N 2 Sungai Penuh. The data on the assessment of learning outcomes were taken from the results of the pretest and posttest which were then processed through paired t-test statistics. According to Ross \& Willson (2018). A paired sample t-test comparing the mean of two groups of matched persons or cases, or comparing the mean of one group, is examined at two different time points. Prior to the t-paired data test, a normality test was first performed as a prerequisite for the paired t-test, Normality test result can be seen in Table 1.

Table 1

Normality test results

\begin{tabular}{l|l|l|l|l|l|l}
\hline & \multicolumn{3}{|l|}{ Kolmogorov-Smirnov $^{\text {a }}$} & \multicolumn{3}{l}{ Shapiro-Wilk } \\
\cline { 2 - 7 } & Statistic & Df & Sig. & Statistic & Df & Sig. \\
\hline Pretest & .163 & 18 & $.200^{*}$ & .902 & 18 & .063 \\
Postest & .117 & 18 & $.200^{*}$ & .978 & 18 & .931 \\
\hline
\end{tabular}

*. This is a lower bound of the true significance. 
The results of the normality test showed that the data were normally distributed where the significant value of each data was $>$ from 0.05 . This shows that the data obtained can be continued for the paired t-test. The following are result of $t$ - paired test (Table 2).

Table 2

Results of t-paired test

\begin{tabular}{|c|c|c|c|c|c|c|c|c|}
\hline & \multicolumn{5}{|c|}{ Paired Differences } & \multirow{3}{*}{$T^{\top}$} & \multirow[t]{3}{*}{ Df } & \multirow[t]{3}{*}{ Sig. (2-tailed) } \\
\hline & \multirow[t]{2}{*}{ Mean } & \multirow[t]{2}{*}{\begin{tabular}{|l} 
Std. \\
Deviation
\end{tabular}} & \multirow[t]{2}{*}{$\begin{array}{l}\text { Std. } \\
\text { Error } \\
\text { Mean }\end{array}$} & \multicolumn{2}{|c|}{$\begin{array}{ll}95 \% \text { Confidence } \\
\text { Interval of the } \\
\text { Difference }\end{array}$} & & & \\
\hline & & & & Lower & Upper & & & \\
\hline $\begin{array}{c}\text { Pair } 1 \\
\text { test }\end{array}$ & $\begin{array}{l}- \\
45.00 \\
000\end{array}$ & 11.11438 & 2.61968 & -50.52705 & -39.47295 & -17.178 & 17 & .000 \\
\hline
\end{tabular}

The results of the analysis of the pretest and posttest results can be seen in table 4.10 where the t-count value obtained is 17,178 which when compared to the t-table is 2.10982 at the $95 \%$ significant level $(\alpha=0.05)$, then $t$ count $>t$ table. That way, if it is connected with the hypothesis made, the conclusions that can be drawn are that $\mathrm{Ho}$ is rejected and $\mathrm{Ha}$ is accepted. Ha: $\mu_{1} \neq \mu_{2}$ (there is a difference). The results of the student response questionnaire after the large group test also showed the total score obtained was 741 with a percentage of $82.33 \%$ included in the $81 \%-100 \%$ interval with the "very good" criteria.

Based on the results of validation by media experts and material experts, teacher assessments, student responses, guided inquiry-based blended learning worksheets and science process skills have been suitable for use in learning redox reaction chemistry in SMK, this is in line with the opinion of Widjayanti (2008) which states that LKPD is one of the learning resources that can be developed by educators as facilitators in learning activities. The prepared LKPD can be designed and developed according to the conditions and situations of the learning activities to be carried out. The advantage of using LKPD as a source of learning for students is that it makes it easier for educators to carry out learning, while for students LKPD facilitates the independent learning process and actively trains cognitive and critical and creative thinking skills.

Sjukur's research (2013) suggests that blended learning is proven to increase students' motivation and learning outcomes. This certainly cannot be separated from the role of teaching materials in it in supporting blended learning. Permana (2015) stated that learning will take place effectively if it is equipped with teaching materials, in his research which developed a blended learning-based biology textbook which from the research results of blended learning-based textbooks could improve the ability of students in facing the challenges of the 21st century, especially in digital skills. literacy and communication. In line with Wijayanti's et al. (2017) research state that the development of blended learning teaching materials provides an alternative learning system that can be applied by teachers that is useful for improving students' ICT skills in accordance with the demands of 21st century competencies and providing solutions for teachers who lack time in delivering material. 
According to Prayitno (2015) that the process of implementing blended learning cannot just happen, that in implementing it there are several aspects to consider, namely the characteristics of the learning objectives to be achieved, relevant learning activities and choosing which activities are relevant to conventional and which activities are relevant. for online learning. Thus, to develop teaching materials for blended learning, a learning model is needed that is in accordance with the learning objectives and can be considered for blended learning.

One of the suitable learning models for blended learning is the guided inquiry learning model. This is in line with the research by Wardani \& Firdaus (2019) which states that the effect of applying a guided inquiry model based on blended learning is effective in improving learning outcomes in the cognitive and psychomotor domains of students in the buffer solution material, besides that this guided inquiry learning model also provides more opportunities. for students to reflect on learning, gain a deeper understanding, so as to optimize the cognitive and psychomotor abilities of students.

The opinion of Nisrina et al. (2020) in their research states that blended learning-based worksheets are very effective and practical in today's learning and can be used for learning with 21st century learning models. Blended learning is chosen with the aim of meeting the needs of students to learn at home and at school and provide solutions for teachers in optimizing lesson hours so that learning objectives are achieved optimally. Based on the results of this study and previous relevant research, it can be concluded that the LKPD that has been developed can be used as a learning resource in blended learning and this LKPD has the potential to improve students' science process skills and maximize the achievement of learning objectives, especially in reduction and oxidation reactions.

\section{Conclusion}

Student' worksheet blended learning based on guided inquiry and science process skills on redox reaction materials for SMK students has been feasible to be used in learning with feasibility based on material expert validation and media expert validation, teacher assessments and student responses. The results of the development of student worksheet blended learning based on guided inquiry and science process skills on the material of reduction and oxidation reactions for SMK students are effectively used in blended learning and have the potential to improve students' science process skills. This is reinforced by the evaluation of student learning outcomes which show a significant difference in the average value before (pretest) and after (posttest) learning using student worksheet which was analyzed using paired $t$-test statistics and the results obtained were $t$ count $>t$ table, $t$ count of 17,178 which when compared with the t-table of 2.10982 at the $95 \%$ level of significance ( $a$ $=0.05)$.

\section{Acknowledgment}

The author would like to thank all those who have joined, especially the chemistry teachers and students at SMK Negeri 2 Sungai Penuh for their contributions and cooperation during the research. 


\section{References}

Aprilia, D. R., Sesunan, F., \& Suana, W. (2019). Pengembangan LKS model blended learning berorientasi HOTS pada materi usaha dan energi. Journal of Komodo Science Education, 1(2), 4559.

Astuti, Y., \& Setiawan, B. (2013). Pengembangan lembar kerja siswa (LKS) berbasis pendekatan inkuiri terbimbing dalam pembelajaran kooperatif pada materi kalor. Jurnal Pendidikan IPA Indonesia, 2(1), 88-92. DOI:10.15294/jpii.v2i1.2515

Harmon, D. A., \& Jones, T. S. (2005). Elementary education: A reference handbook. ABC-CLIO.

Khofifah, I. N., \& Mitarlis, M. Student worksheet oriented on science, technology, engineering, and mathematics (STEM) with PjBL model on acid base matter by using natural product. Jurnal Pendidikan Kimia, 13(1), 22-37. DOI: 10.24114/jpkim.v13i1.24141

Kristyowati, R. (2018). Lembar Kerja peserta didik (LKPD) IPA sekolah dasar berorientasi lingkungan. Prosiding Seminar dan Diskusi Pendidikan Dasar, 282-287.

Lee, W. W., \& Owens, D. L. (2004). Multimedia-based instructional design: Computer-based training, web-based training, distance broadcast training, performance-based solutions. John Wiley \& Sons.

Lukman, I., Damanik, M., Silaban, S., \& Kembaren, A. (2019). Development of problem based learning innovative student worksheets in learning the concept of chemistry for senior high school students. Journal of Transformative Education and Educational Leadership, 1(1), 23-28.

Mufarohah, S. L., \& Dwiningsih, K. (2018). The effectiveness of blended learning oriented lks with pogil strategy on high school chemical bond subject. JKPK (Jurnal Kimia dan Pendidikan Kimia), 3(2), 53. DOI:10.20961/jkpk.v3i2.22328

Munadi, Y. (2008). Media pembelajaran sebuah pendekatan baru. Jakarta: Gaung persada press.

Nisrina, N., Jufri, A. W., \& Gunawan, G. (2020). Pengembangan LKPD berbasis blended learning untuk meningkatkan literasi sains peserta didik. Jurnal Pijar Mipa, 15(3), 192. DOI:10.29303/jpm.v15i3.1880

Permana, F. H. (2015). Pengembangan buku ajar biologi berbasis blended learning sebagai bekal hidup di abad 21 untuk mahasiswa S1 Kimia FMIPA UM. Prosiding Seminar Nasional Pendidikan Biologi, 58, pp. 50-61.

Prayitno, W. (2015). Implementasi blended learning dalam pembelajaran pada pendidikan dasar dan menengah. Jurnal Pendidikan, 6(01).

Ross, A., \& Willson, V. L. (2018). Basic and advanced statistical tests: Writing results sections and creating tables and figures. Springer.

Sharma, P. (2010). Blended learning. ELT Journal, 64(4), 456-458. DOI:10.1093/elt/ccq043

Silaban, S. (2021). Pengembangan program pengajaran. Medan: Yayasan Kita Menulis.

Sjukur, S. B. (2013). Pengaruh blended learning terhadap motivasi belajar dan hasil belajar siswa di tingkat SMK. Jurnal Pendidikan Vokasi, 2(3). DOI:10.21831/jpv.v2i3.1043

Trianto. (2007). Model pembelajaran inovatif. Jakarta: Bumi Aksara.

Trilling, B., \& Fadel, C. (2009). 21st century skills: Learning for life in our times. John Wiley \& Sons.

Wardani, S., \& Firdaus, L. (2019). Pengaruh model inkuiri terbimbing berbasis blended learning terhadap kemampuan kognitif-psikomotor pada materi larutan penyangga. JTK (Jurnal Tadris Kimiya), 4(2), 189-201. DOI:10.15575/jtk.v4i2.5404

Widjayanti. (2008). Media lembar kerja peserta didik. Jakarta: Rineka.

Wijayanti, W., Maharta, N., \& Suana, W. (2017). Pengembangan perangkat blended learning berbasis learning management system pada materi listrik dinamis. Jurnal Ilmiah Pendidikan Fisika Al-Biruni, 6(1), 1-12. DOI:10.24042/jpifalbiruni.v6i1.581 